\title{
ANALISIS KONTEN KREATIF PADA FANPAGE FACEBOOK CADBURY DAIRY MILK TAHUN 2016 Amanda Fidienna Putri ${ }^{1)}$, Tuti Hartati ${ }^{2)}$ dan Titik Purwinarti ${ }^{3)}$ \\ Jurusan Administrasi Niaga, Politeknik Negeri Jakarta \\ Email: ${ }^{1}$ amandafidiennaputri@gmail.com , ${ }^{2}$ tuti.hartati@yahoo.co.id, 33titikpurwinarti@yahoo.com
}

\begin{abstract}
This research aims to find out what content is liked by fans and to find what message elements are contained in the creative content on fanpage facebook Cadbury Daiy Milk. This method research is using quantitative content analys research by coding method. This reaserch involved three (3) reseachers whose result would be compared to each other. The population in this research is the all content on fanpage facebook Cadbury Dairy Milk in 2016 and using random sample to conduct this research. This reaserch examined 4 unit of analysis in which already categorized. Based on the result of the Coefisien Reliable (CR) test show that the sample of data doesn't exist less then 0,95 or <0,95. 60 samples that have been research get result more than 0,95 or >0,95. The data states that the content in fanpage facebook Cadbury Dairy Milk is reliable with 4 units of analysis.
\end{abstract}

Keywords: Fanpage Facebook, Cadbury Dairy Milk, content creative, copywriting, quantitative content analys, and coding method.

\section{Abstrak}

Penelitian ini bertujuan untuk mengetahui konten apa saja yang disukai oleh penggemar dan untuk mengetahui unsur pesan yang terdapat dalam konten kreatif pada fanpage facebook Cadbury Daiy Milk. Metode penelitian ini menggunakan penelitian analisis kuantitatif dengan metode pengkodean. Penelitian ini melibatkan tiga (3) peneliti yang hasilnya akan dibandingkan satu sama lain. Populasi dalam penelitian ini adalah semua konten pada fanpage facebook Cadbury Dairy Milk pada tahun 2016 dan menggunakan sampel acak untuk melakukan penelitian ini. Penelitian ini menguji 4 unit analisis yang sudah dikategorikan. Berdasarkan hasil uji Coefisien Reliable (CR) menunjukkan bahwa sampel data tidak ada kurang dari 0,95 atau <0,95. 60 sampel yang telah diteliti mendapatkan hasil lebih dari 0,95 atau> 0,95. Data menyatakan bahwa konten dalam fanpage facebook Cadbury Dairy Milk dapat diandalkan dengan 4 unit analisis.

Kata Kunci: fanpage facebook, Cadbury Dairy Milk, Konten Kreatif, Copywriting, Analisis Kuantitatif, Metode koding

\section{PENDAHULUAN \\ Latar Belakang}

Perkembangan

mempermudah zaman

semakin manusia untuk berhubungan satu sama lain, menemukan dan memberikan informasi serta bergerak secara cepat dan tepat. Internet adalah salah satu dari sekian banyak kemajuan yang mendukung mobilitas manusia menjadi lebih luas dan mudah. Salah satu keunggulan internet adalah menjadi wadah komunikasi yang dapat menjangkau hampir seluruh lapisan masyarakat.
Terlihat dari munculnya berbagai jenis social media yang dewasa ini sangat akrab dikalangan masyarakat.

Salah satu alasan mengapa social media sangat dekat dengan masyarakat adalah karena manusia merupakan mahluk sosial yang selalu bergantung pada manusia lainnya.

Karena fenomena inilah dilihat sebagai keuntungan bagi pemilik usaha agar dapat memasarkan produknya secara langsung. Penyebaran informasi yang cepat membuat para pengusaha mulai melirik social media 
sebagai lahan untuk berpromosi. Hal inilah yang menjadi sebuah tantangan bagi industri kreatif dalam melaksanakan peranannya sebagai komunikator, yang ingin menyampaikan pesan dengan cara yang menarik dan mudah dipahami oleh pembaca. Dengan segala kemudahan teknologi yang tersedia, banyak produsen yang berlomba-lomba untuk menyentuh target pasarnya melalui soft selling. Social media bukan hanya berperan untuk wadah komunikasi antar personal, tapi juga sabagai wadah periklanan yang digunakan oleh perusahaan demi mencapai sesuatu yang ditargetkan.

Di sini penulis mengamati, bahwa kini iklan merambah ke dunia Social Media. Menggunakan konten-konten menarik dan kreatif untuk menjadi lebih dekat dengan pangsa pasar produk tersebut. Sebagai contoh salah satu brand yang menggunakan social media sebagai wadah promosi ialah Cadbury, dengan nama Fanpage: Cadbury Dairy Milk, Twitter: @Cadburyid, dan Instagram: CadburyID. Berdasarkan fans yang tercatat pada Fanpage sebanyak lebih dari 14.3 juta fans dangan pangsa pasar remaja perempuan.

Cadbury Dairy Milk adalah salah satu contoh produk yang berusaha menyentuh pasarnya dengan cara soft selling melalui social media. Konten yang disajikan menggunakan visual, caption, dan copy image, agar bisa menarik perhatian fans. Alasan itulah penulis tertarik untuk mengetahui tetang isi pesan pada konten kreatif yang disajikan di Fanpage Facebook Cadbury Dairy Milk.

Maka dari itu berdasarkan penjelasan di atas penulis memilih judul "Analisis Konten Kreatif pada Fanpage Facebook Cadbury Dairy Milk Tahun 2016”. Dengan mengangkat judul tersebut peneliti dapat meneliti makna isi pesan kreatif yang terdapat dalam Kontent Iklan Fanpage Facebook Cadbury Dairy Milk. Dengan demikian peneliti dapat memberi masukan terhadap isi konten tersebut agar lebih baik dan bisa tepat sasaran antara isi konten dan target pasarnya yaitu remaja perempuan.

\section{Tujuan}

Dari latar belakang di atas dapat ditarik kesimpulan bahwa tujuan dari penelitian ini ialah mengetahui konten seperti apa yang disukai oleh fans fanpage facebook Cadbury Dairy Milk dan element pesan apa saja yang terdapat dalam konten kreatif di fanpage facebook Cadbury Dairy Milk.

\section{Permasalahan}

Dari uraian latar belakang dan identifikasi masalah di atas, penulis menetapkan masalah yang akan dibahas. Rumusan masalah yang akan penulis ambil adalah "Apa Isi Pesan Konten Kreatif pada Fanpage Facebook Cadbury Dairy Milk 2016?”

\section{Kajian Pustaka}

Penelitian ini didasarkan pada beberapa teori sebagai berikut.

\section{Definisi Iklan}

Menurut Bovee, $(1992,7)$ menyatakan, Iklan adalah komunikasi nonpersonal informasi, biasanya dibayar dan biasanya persuasif tentang suatu produk, jasa atau ide oleh sponsor, diidentifikasi melalui berbagai media.

Selanjutnya menurut Kotler dan Amstrong. (2012, 454) menyatakan, Iklan adalah segala bentuk penyajian dan promosi ide, barang atau jasa secara nonpersonal oleh suatu sponsor tertentu yang memerlukan pembayaran.

Sementara itu menurut Kasali, (1992, 21) Secara sederhana iklan didefinisikan sebagai pesan yang menawarkan suatu produk yang ditujukan oleh masyarakat lewat suatu media.

Dari pengertiaan ketiga para ahli tersebut dapat ditarik kesimpulan bahwa periklanan merupakan sebuah komunikasi mengenai produk atau jasa yang ditunjukan untuk masyarakat agar tertarik dan mau untuk mencoba produk tersebut. 


\section{Tujuan Iklan}

Tujuan periklanan menurut Colley dalam (Kotler, 1988: 281) memiliki 3 variabel utama, yaitu menyampaikan informasi produk, meyakinkan dan mengingatkan. Sedangkan tujuan periklanan menurut Kotler dalam Durianto, (2003:3) diuraikan sebagai berikut:

a. Periklanan menjalankan sebuah fungsi informasi

Biasanya dilakukan secara besarbesaran pada tahap awal suatu jenis produk. Tujuannya untuk membentuk permintaan pertama.

b. Periklanan menjalankan sebuah fungsi persuasive

Penting dilakukan dalam tahap kompetitif. Tujuannya untuk membentuk permintaan selektif untuk suatu merek tertentu.

c. Periklanan menjalankan pengingat

Bentuk iklan yang berhubungan dengan iklan ini adalah iklan penguat, yang bertujuan meyakinkan pembeli bahwa sekarang mereka telah melakukan pilihan yang benar.

\section{Iklan Internet}

Seiring dengan ditemukannya World Wide Web, sebuah sistem jaringan lebar (network-wide), peta periklanan mulai berubah. Social media menjadi lebih mudah bagi kepentingan bisnis untuk menyebarkan informasi dan meraih pelanggan. Inilah yang disebut Internet Advertising atau biasa disingkat IAdvertising. Secara harfiah dapat diterjemahkan menjadi periklanan atau beriklan di internet. Iklan internet memenuhi standar nonpromosi yang telah ditetapkan secara informal.

Para "surfer" akan mencurahkan perhatian pada situs yang menawarkan informasi. Mereka akan melihat untuk membeli, tetapi mereka tidak mau dijual secara agresif. Pemasar harus bisa menyalurkan informasi keunggulan merek tanpa dianggap sedang berdagang (Shimp, 2003:5). Saluran terbaru untuk pemasaran langsung adalah elektronik.
Internet memberikan pemasar dan konsumen peluang interaksi dan individualisasi yang jauh lebih besar. Pemasaran interaktif menawarkan banyak manfaat unik. Efektif dalam menjangkau orang sepanjang hari (Kotler, 2007:298299).

Ray dalam (Morissan, 2010:16) menambahkan dua element dalam promotion mix yaitu Direct Marketing dan Interactive media dua element terakhir ini telah digunakan secara luas pengelola pemasaran untuk berkomunikasi dengan khalayak atau sasarannya sebagaimana empat element sebelumnya

\section{Facebook}

Ada 9 Fitur yang ditawarkan Facebook sebagai situs jejaring sosial membuat banyak orang menggunakannya. Menurut (Jubilee Enterprise, 2010:79), Indonesia merupakan salah satu pengguna Facebook terbesar dengan jumlah user sekitar 17,6 juta orang. Menurut Marindo dkk, (2011:5) social media memiliki manfaat-manfaat berikut dalam kehidupan sehari-hari:

a. Personal branding is not only public figure, it's for everyone

b. Fantastic marketing result through social media

\section{Fasilitas Facebook}

Kurniawan (2009:65) menyatakan bahwa facebook memiliki beberapa fasilitas untuk menjadi sebuah wadah promosi suatu produk:

a. Fasilitas Wall Facebook

Fasilitas wall facebook adalah fasilitas yang sering digunakan orang untuk menuliskan pesan atau celotehan di dinding atau di halaman depan profile facebook. Fasilitas wall facebook ini juga bisa dibagikan kepada teman lainnya dengan menekan button share, sehingga bisa memberikan reactions, like, dan comment.

b. Messages

Messages pada facebook berfungsi sebagai pengirim pesan secara personal 
antar teman. Bisa digunakan sebagai promosi karena bisa menjawab pertanyaan fans secara personal.

c. Reactions, Comment, and shares

Reactions, comment, and shares merupakan fitur yang membuat teman atau fans dalam facebook menyatakan apakah mereka menyukai postingan kita atau tidak. Semakin banyak Reactions yang diberikan semakin memberikan penilaian mengenai postingan yang kita post, semakin sering postingan kita di share dan comment maka semakin banyak people yang melihat postingan tersebut.

d. Fan page Facebook atau Halaman Penggemar

Halaman penggemar atau Fan page adalah fasilitas yang disediakan oleh facebook yang memungkinkan user untuk mengumpulkan teman sebanyakbanyaknya sekaligus dapat langsung mempromosikan dan menjual produk yang dijual. Halaman ini hampir mirip dengan tampilan profile facebook namun fan page atau halaman penggemar bisa mempromosikan produk tanpa mengganggu profile facebook pribadi kita.

\section{Content Kreatif}

Menurut Kasali, (1995:76), Dalam hal ini kata kreatif diartikan sebagai:

Suatu kemampuan seseorang (atau sekelompok orang) yang memungkinkan mereka menemukan pendekatanpendekatan atau terobosan baru dalam menghadapi situasi atau masalah tertentu, yang biasanya tercermin dalam pemecahan masalah dengan cara baru dan unik yang berbeda dan lebih baik dari sebelumnya"

Kata kreatif merupakan kata yang sangat umum digunakan dalam dunia iklan. Dalam hal ini proses kreatif mencakup pelaksanaan dan pengembangan konsep ide yang dapat mengemukakan strategi pasar dalam bentuk komunikasi yang efektif. Termasuk di dalamnya adalah membuatan headline, perwajahan, naskah; baik dalam bentuk kopi untuk iklan media cetak, script untuk iklan radio, dan storyboard untuk iklan televisi. Secara garis besar proses kreatif yang dipaparkan berikut ini disadur dari pendapat Gilson dalam (Kasali, 1995:65) Menuliskan bahwa:

Format pesan yang disampaikan oleh komunikator harus mencolok, dibuat dengan menggunakan unsur yang menarik perhatian, seperti kontras, unsurunsur baru, gambar menarik, terdapat pokok berita, format khas, ukuran, posisi pesan, warna dan perasaan yang ingin ditimbulkan. Kesemuanya harus diperhatikan, agar pengeksekusian pesan bisa sesuai apa yang diharapkan.

Lalu menurut Durianto, (2003:97), keberadaan kredibilitas pesan juga harus dipenuhi. Ada tiga faktor yang mendasari kredibilitas sumber pesan, yaitu:

a. Keahlian yang merupakan pengetahuan khusus yang dimiliki oleh komunikator dan mendukung kehebatan produk.

b. Sifat terpecaya, yaitu seberapa obyektif dan jujur sumber khalayak

c. Sifat disukai, merupakan daya tarik sumber terhadap khalayak

\section{Copywriting}

Agustrijanto (2006: 21). Berpendapat bahwa, Copywriting harus mampu untuk menggugah, menarik, memindahkan, mengidentifikasi, menggalang kebersamaan, dan juga mengkomunikasikan pesan dengan nilai komparatif pada masyarakat (2006:19).

Arti secara ringkas dari copywriting menurutnya adalah karya tulis atau salinan Copywriter.

Sementara menurut Jefkins dalam (Agustrijanto, 2006:33)",

Copywriting adalah seni penulisan pesan penjualan yang paling persuasif dan kuat, yang dilatarbelakangi oleh kewiraniagaan melalui media cetak. Pengertian lain dalam buku Agustrijanto tersebut adalah bahwa Copywriting merupakan tulisan dengan ragam gaya dan pendekatan yang dihasilkan dengan cara kerja keras 
melalui perencanaan dan kerjasama dengan klien, staf legal, account executive, peneliti, dan juga direktur seni.

\section{Unsur-unsur Copywriting}

Agustrijanto, (2002:55) juga membagi unsur-unsur copywriting sebagai berikut: Unsur AIDCA
a) Attention (menarik perhatian)
b) Interest (menciptakan minat)
c) Desire (memunculkan hasrat
d) Conviction (memberi keyakinan)
e) Action (menyegerakan aksi)

Rumus copywriting

a) Kata bersifat menyegerakan

b) Menarik perhatian

c) Membangun image positif

d) Efektif dan efisien

e) Gaya dan jenis kata Copywriting

Eksploratif

a) Mengulas dengan tajam hakikat produk dengan kata-kata yang akurat

b) Kata-kata yang digunakan tidak boleh barmakna ganda.

Naratif

a) Menguraikan produk dalam bentuk cerita. Gaya bahasa dibuat semenarik mungkin

b) Pilihan katanya mengandung majinasi dan membuai dengan tetap mengedepankan kebenaran fakta

Argumentatif

a) Naskah iklan bersifat mempengaruhi audience secara jelas dan nyata.

b) Gaya dan jenis kata jelas menyerang kompetitor atau mengukuhkan kelebihan produknya sendiri agar target audience

Retoris

a) Mengungkap kebenaran sejujurnya tanpa mengharap jawaban atau komentar.

b) Sejak awal diproyeksikan agar tidak ada bantahan terhadapnya.

Normatif

a) Menginformasikan secara mendetail tentang produk.

b) Sejumlah data yang mneunjang disampaikan komunikatif dan menghindari news style meski hakikatnya memang informasi juga

\section{Daya Tarik Pesan}

Untuk menyampaikan pesan dalam sebuah iklan pasti memerlukan daya tarik dari apa yang ingin disampaikan. Semakin menarik biasanya pesan yang ingin disampaikan akan lebih mudah dibaca atau diterima oleh khalayak. Angle daya tarik yang digunakan pun berbeda-beda tergantung apa yang ingin disampaikan oleh komunikator.

\section{Daya Tarik Selebritis}

Produk atau merek dapat menonjol dalam periklanan salah satunya dengan menggunakan daya tarik para figur masyarakat (Suyanto, 2004:2). Figur masyarakat tersebut dapat berupa seorang tokoh, bintang TV, aktor, aktris, atlet, ilmuwan dan sebagainya. Pengiklan atau agensi iklan menggunakan selebritis yang sesuai dengan pasar sasaran dan berharap dapat mempengaruhi sikap dan perilaku konsumen terhadap produk yang diiklankannya.

\section{Daya Tarik Humor}

Pengiklan juga menggunakan humor untuk mencapai sasaran komunikasi yang bervariasi agar memicu perhatian, memandu konsumen secara menyeluruh terhadap tuntutan produk, mempengaruhi sikap, menyempurnakan kemampuan "recall" dari tuntutan pengiklan dan pada akhirnya menciptakan tindakan konsumen untuk membeli produk.

\section{Daya Tarik Rasional}

Daya tarik rasional menekankan pada manfaat produk seperti kualitas, harga, value, atau kinerja. Daya tarik rasional berfokus pada praktek, fungsi atau kebutuhan konsumen secara optimal terhadap suatu produk, yang memberikan tekanan pada manfaat atau alasan untuk mempunyai atau menggunakan suatu merek. Isi dari pesan menekankan pada fakta, belajar dan persuasi logis. 


\section{Daya Tarik Emosional}

Daya tarik emosional berusaha memanfaatkan emosi positif (seperti humor, cinta, rasa bangga, rasa senang, dan sejenisnya) dan emosi negatif (seperti rasa takut, rasa bersalah, malu, tegang, sedih, waswas, dan seterusnya). Daya tarik emosional berhubungan dengan kebutuhan psikologis konsumen untuk membeli suatu produk.

\section{Gaya dalam Pelaksanaan Pesan}

Biasanya, seorang produsen mempunyai gaya sendiri untuk memperkenalkan produk atau jasa yang mereka iklan kan. Ada banyak gaya bahasa yang nantinya akan saling berhubungan dengan produk yang akan dijual.

\section{Menjual Langsung}

Menjual langsung (straight sell) Gaya menjual langsung tertuju langsung pada informasi produk atau jasa. Gaya eksekusi ini sering digunakan bersama daya tarik rasional yang memfokuskan pesan pada produk atau jasa serta manfaat dan atau atribut spesifiknya (Suyanto, 2008:1).

\section{Potongan Kehidupan (slice of life)}

Menurut (Suyanto, 2008:4), Potongan kehidupan atau Slice of life adalah Menunjukkan satu atau beberapa orang yang menggunakan produk tersebut dalam keadaan normal. Umumnya berdasarkan pada pendekatan pemecahan masalah sehari-hari. Kemudian pengiklan menunjukkan bahwa produk yang diiklankan sebagai pemecah masalah. Pengiklan menyukai gaya ini, karena percaya bahwa gaya ini efektif untuk menyajikan situasi yang sebagian besar konsumen mendapatkan manfaat dari kelebihan produk tersebut

\section{Gaya Kehidupan}

Menekankan bagaimana suatu produk sesuai dengan suatu gaya hidup konsumen Menurut Kotler dalam (Suyanto, 2008:7), "Gaya hidup adalah pola hidup seseorang di dunia yang diekspresikan dalam aktivitas, minat, dan opininya. Gaya hidup menggambarkan "keseluruhan diri seseorang” dalam berinteraksi dengan lingkungannya.”

\section{Fantasi}

Gaya penulisan fantasi (fantasy) menggunakan pendekatan dengan menciptakan fantasi di sekitar produk tersebut atau penggunaannya (Suyanto, 2008:9). Produk menjadi bagian pusat dari situasi yang diciptakan oleh pengiklan.

\section{Suasana atau Citra}

Membangkitkan suasana atau citra di sekitar produk tersebut, seperti kecantikan, cinta, atau ketenangan. Tidak ada pengakuan atas produk tersebut kecuali melalui sugesti, terutama yang sedang mencari citra "canggih" dan "global" (Suyanto, 2008:11).

\section{METODE PENELITIAN}

Metode penelitian yang dipakai peneliti pada penelitian ini adalah metode analisis isi (content analysis), analisis isi adalah metode yang sistematis untuk menganalisis isi dan bagaimana pesan itu disampaikan, disebutkan bahwa analisis isi menjadi berguna karena dapat memprediksi siapa yang menyampaikan pesan-pesan, dan bagaimana pesan itu disampaikan.

Metode analisis isi terdiri dua jenis, yaitu analisis isi kualitatif dan kuantitatif, penggunaan analisis satu jenis kuantitatif saja, tidak akan mencerminkan jawaban yang komprehensif terhadap pertanyaanpertanyaan yang diajukan. Untuk itu, analisis isi kuantitatif perlu diikuti analisis isi kualitatif. Metode analisis isi sebagai bentuk kegiatan membaca, menonton dan mendengar pesan dari media dalam skala yang luas dengan melakukan perhitungan terhadap hal yang ditangkap dari media tersebut.

Analisis isi adalah suatu teknik sistematis untuk menganalisis isi pesan dan mengolah pesan atau suatu alat untuk 
mengobservasi dan menganalisis isi perilaku komunikasi yang terbuka dari komunikator yang terpilih (Kriyantono, 2006: 230-231).

Sistematik berarti bahwa prosedur yang digunakan untuk analisis diterapkan dengan cara yang sama pada semua isi yang nantinya akan dianalisis. Selain itu kategori juga ditetapkan sama sehingga isinya bisa relevan. Dengan kata lain sistematik berarti analisis dirancang untuk memperoleh data yang relevan dengan masalah penelitian yang diseleksi terlebih dahulu. Analisis data ini didasarkan pada langkah-langkah yang terencana agar tidak bias.

\section{Analisis isi Kuantatif}

Analisis isi kuantitatif merupakan salah satu metode untuk mempelajari dan menganalisis komunikasi secara sistematik, objektif, dan kuantitatif terhadap pesan yang tampak.

Sementara menurut Budd dalam (Kriyantono, 2016:232),

Analisis isi adalah suatu teknik sistematis untuk menganalisis isi pesan dan mengolah pesan atau suatu alat untuk mengobservasi dan menganalisis isi perilaku komunikasi yang terbuka dari komunikator yang dipilih.

Tujuan dari penggunaan analisis isi ini sendiri menurut McQuail dalam (Kriyantono, 2006:233) ialah mendeskripsikan, membuat perbandingan, mengetahui fungsi dan efek media,mengeveluasi media performance, serta mengetahui apakah dalam iklan tersebut ada bias atau tidak.

\section{Subjek Penelitian}

Penelitian dilakukan pada isi konten iklan pada fanpage facebook Cadbury Dairy Milk pada bulan 2016. Penulis hanya akan meneliti bagian isi pesan kontennya saja.

\section{Teknik Pengumpulan Data}

Dalam penelitian ini, peneliti akan menggunakan beberapa cara dalam teknik pengumpulan data, berikut adalah beberapa teknik yang peneliti gunakan dalam pengumpulan data:

\section{Dokumentasi}

Dalam penelitian ini teknik pengumpulan data dilakukan dengan dokumentasi. Teknik ini dilakuka dengan cara meminta dokumen dari pemilik dokumen untuk dijadikan obyek penelitian. Dalam hal ini, mengunduh obyek penelitian dari Fanpage Facebook Cadbury Dairy Milk tahun 2016.

\section{Kepustakaan}

Teknik pengumpulan data melalui pustaka yang dimaksudkan untuk melengkapi data dan pengetahuan berkaitan dengan masalah yang diteliti. Data tersebut diperoleh dari referensi buku, majalah, jurnal ataupun situs yang berhubungan dengan penelitian tersebut.

\section{Unit Analisis dan Kategori}

Unit analisis yang digunakan untuk mengidentifikasikan dan mengungkapkan secara deskriptif karakteristik dari karakteristik isi pesan kreatif dari iklan di fanpage facebook Cadbury Dairy Milk. Kategori unit analisis adalah penempatan kriteria tertentu yang relevan dengan unit analisis.

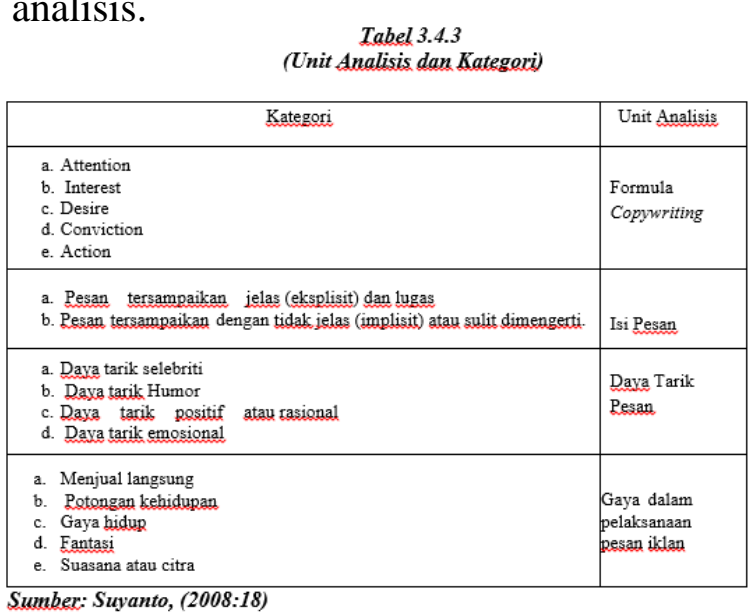

\section{Teknik Analisis Data}

Proses analisis dilakukan secara bersamaan dengan proses pelaksanaan pengumpulan data. Dalam penelitian ini data-data yang dianalisis berupa dokumen. 
Teknik analisa data yang digunakan dalam mengolah data adalah analisis deskriptif kualitatif. Teknik analisa data yang digunakan dalam mengolah data adalah analisis deskriptif kualitatif. Data yang diperoleh melalui pemahaman secara langsung (tekstual) dimana dari lembaran coding sheet yang memuat unit-unit analisa dan kategorinya, foto iklan online dari Fan Page Facebook Cadbury Daury Milk tahun 2016.

Kemudian hasil dari coding sheet tersebut dianalisis dan digunakan untuk menjawab pertanyaan dari rumusan masalah di penelitian ini. Karena, coding adalah suatu proses dimana data mentah ditransformasikan kepada unit-unit yang memungkinkan untuk membuat karakteristik isi yang relevan (Setiawan, 1982:63).

\section{Metode Penentuan Populasi dan Sampel}

Untuk mempermudah penulis, penelitian kalo ini akan menggunaka data populasi dari fanpage facebook Cadbury Dairy Milk dan mengambil sampel sesuai dengan teori yang sudah ditentukan.

\section{Populasi}

Menurut Sugiono (2007:115). pengertian populasi adalah sebagai berikut: Populasi adalah wilayah generalisasi yang terdiri dari objek atau subjek yang mempunyai kualitas dan karakteristik tertentu yang ditetapkan oleh penelitian untuk dipelajari dan kemudian ditarik kesimpulan.

Dalam penelitian ini, yang menjadi populasi adalah seluruh konten pada Fan Page Facebook Cadbury Dairy Milk pada tahun 2016. Banyaknya populasi dalam penelitian ini adalah sebanyak 144 konten.

\section{Sampel}

Sampel adalah bagian dari jumlah dan karakteristik yang dimiliki oleh populasi tersebut (Sugiyono, 2012:120). Sampel adalah bagian dari populasi, sehingga sampel representative benarbenar mencerminkan dari populasinya.
Sampel diambil sebagai sumber data dan dapat mewakili seluruh populasi. Jika subjek kurang dari 100, maka lebih baik diambil semua, sehingga penelitian merupakan penelitian populasi. Sampel tersebut didapat berdasarkan perhitungan rumus Slovin yang dikutip dari Kriyantoono, (164:2006)

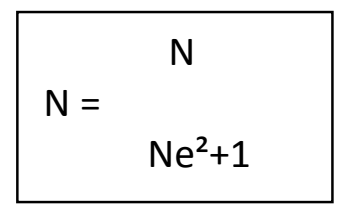

\section{Keterangan:}

$$
\begin{array}{ll}
\mathrm{N} & =\text { Ukuran sampel } \\
\mathrm{Ne}^{2} & =\text { Ukuran Populasi } \\
\mathrm{E} & =\text { Kategori ketidaktelitian karena } \\
& \text { kesalahan pengambilan sampel } \\
& \text { yang dapat ditoleri }
\end{array}
$$

Dengan demikian jumlah sampel dalam penelitian ini:

$\begin{aligned} N & =\frac{144}{144(10 \%)^{2}+1} \\ & =59,0\end{aligned}$

Dari pemaparan dan perhitungan di atas, jumlah sampel sama dengan jumlah populasi, yakni sebanyak 59 sampel. Sehingga penelitian kali ini adalah penelitian populasi.

\section{Rancangan Sampling}

Dalam penelitian Analisis isi kali ini akan menggunakan rancangan sampling Random Sederhana. Pada teknik sampling ini anggota populasi mempunyai peluang yang sama untuk dipilih menjadi sampel. Di sini periset akan menulis atau memberi nomor pada seluruh anggota populas, lalu mengundinya (merdom/mengcak samapai mendapatkan jumlah sampel yang dibutuhkan Kriyantono, (154:2006).

\section{Uji Validitas dan Reliabilitas Uji Validitas}

Pengertian dari validitas adalah suatu abstraksi dan generalisasi khusus dan juga merupakan konsep yang diciptakan, 
khusus untuk kebutuhan ilmiah dan mempunyai pengertian yang terbatas (Nasir, 1988: 177). Demi mendapatkan isi dari pesan kreatif iklan yang akan diteliti, unit analisis ditetapkan berdasar kategori yang ada unsure kevaliditasannya. Karena, validitas adalah suatu konsep akurasi (keabsahan) pengukuran suatu variabel dan menunjukkan keabsahan data hasil pengukuran (Sugiyono, 1999:19).

\section{Reliabilitas}

Reliabilitas pada dasarnya adalah merupakan kapasitas data-data yang digunakan dalam proses penelitian untuk memenuhi tingkat obyektivitas tertentu. Reliabilitas berkaitan dengan fungsi keseluruhan rancangan studi yang menyangkut prosedur sampling, prosedur perhitungan, prosedur pengkodingan dan realitas kategori. Salah satu uji reliablitas yang dapat digunakan adalah berdasarkan rumus Ole R. Holsty di mana hasil CR di atas 0.97 menandakan konten tersebut reliable (Kriyantono, 2006:238-239). Di sini peneliti melakukan pretest dengan cara mengkoding sampel ke dalam kategorisasi. Kegiatan ini selain dilakukan peneliti juga dilakukan oleh seseorang yang lain yang ditunjuk peneliti sebagai pembanding atau hakim. Uji ini disebut dengan uji antar code, (Kriyantono, 2006:238-239

\section{HASIL DAN PEMBAHASAN}

Bab hasil penelitian dan pembahasan ini berisi penjelasan mengenai data dan pembahasan temuan penelitian.

\section{Hasil Penelitian Unit Analisis Formula Copywriting}

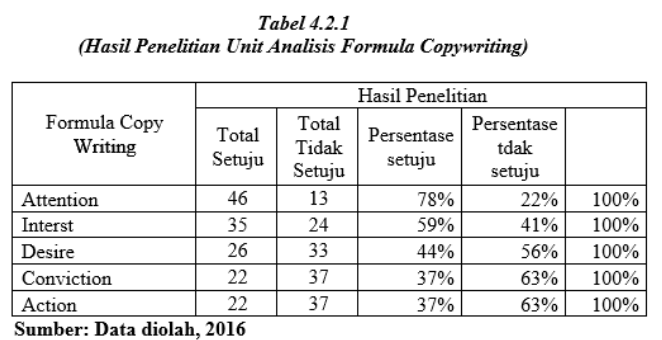

Dari penelitian yang peneliti lakukan dengan 59 sampel pada Fanpage Facebook Cadbury Dairy Milk Tahun 2016. Formula Copy-writing, mendapakan hasil $78 \%$ atau sekitar 46 konten yang disetujui oleh peneliti karena menarik perhatian (Attention).

\section{Hasil Penelitian Unit Analisis Isi Pesan}

Tabel 4.2.2

(Hasil Penelitian Unit Analisis Isi Pesan)

\begin{tabular}{|c|c|c|c|c|c|}
\hline \multirow{2}{*}{ Isi pesan } & \multicolumn{5}{|c|}{ Hasil Penelitian } \\
\cline { 2 - 6 } & $\begin{array}{c}\text { Total } \\
\text { Setuju }\end{array}$ & $\begin{array}{c}\text { Total } \\
\text { Tidak } \\
\text { Setuju }\end{array}$ & $\begin{array}{c}\text { Persentase } \\
\text { Setuju }\end{array}$ & $\begin{array}{c}\text { Persentase } \\
\text { Tidak } \\
\text { Setuju }\end{array}$ & Total \\
\hline $\begin{array}{c}\text { Pesan jelas } \\
\text { (Eksplisit) }\end{array}$ & 59 & 0 & $100 \%$ & $0 \%$ & $100 \%$ \\
\hline $\begin{array}{c}\text { Pesan tidak } \\
\text { jelas (Implisit) }\end{array}$ & 0 & 59 & $0 \%$ & $100 \%$ & $100 \%$ \\
\hline
\end{tabular}

Sumber: Data diolah, 2016

Hasil penelitian untuk unit analisis isi pesan pada 59 sampel fanpage Facebook Cadbury Dairy Milk. Mendapatkan hasil $100 \%$, hal ini menunjukan bahwa pesan yang disampaikan di fanpage facebook Cadbury Dairy Milk tahun 2016 tersampaikan dengan jelas (Eksplisit).

\section{Hasil Penelitian Unit Analisis Daya Tarik Pesan}

Hasil dari penilitian pada untuk unit analisis gaya dalam dalam pelaksanaan pesan, peneliti menemukan bahwa unsur terbanyak adalah potongan kehidupan sebanyak 44 konten.

\begin{tabular}{|c|c|c|c|c|c|}
\hline \multirow[b]{2}{*}{$\begin{array}{l}\text { Daya tarik } \\
\text { pesan }\end{array}$} & \multicolumn{5}{|c|}{ Hasil Penelitian } \\
\hline & $\begin{array}{l}\text { Total } \\
\text { Setuju }\end{array}$ & $\begin{array}{l}\text { Total } \\
\text { Tidak } \\
\text { Setuju }\end{array}$ & $\begin{array}{c}\text { Persentase } \\
\text { setuju }\end{array}$ & $\begin{array}{l}\text { Persentase } \\
\text { tidak setuju }\end{array}$ & Total \\
\hline $\begin{array}{c}\text { Daya tarik } \\
\text { selebritis }\end{array}$ & 17 & 42 & $29 \%$ & $71 \%$ & $100 \%$ \\
\hline $\begin{array}{l}\text { Daya tarik } \\
\text { humor }\end{array}$ & 16 & 43 & $27 \%$ & $73 \%$ & $100 \%$ \\
\hline $\begin{array}{l}\text { Daya tarik } \\
\text { positif atau } \\
\text { rasional }\end{array}$ & 24 & 35 & $41 \%$ & $59 \%$ & $100 \%$ \\
\hline $\begin{array}{l}\text { Daya tarik } \\
\text { emosional }\end{array}$ & 17 & 42 & $299 \%$ & $71 \%$ & $100 \%$ \\
\hline
\end{tabular}

Hasil penelitian analisis Gaya dalam Penyampaian Pesan

Tabel 4.2.4
(Hasil penelitian analisis Gaya dalam Penyampaian Pesan)
\begin{tabular}{|c|c|c|c|c|c|}
\hline $\begin{array}{c}\text { Gaya dalam } \\
\text { pelaksanaan } \\
\text { pesan }\end{array}$ & $\begin{array}{c}\text { Total } \\
\text { Setuju }\end{array}$ & $\begin{array}{c}\text { Total } \\
\text { Tidak } \\
\text { Setuju }\end{array}$ & $\begin{array}{c}\text { Persentas } \\
\text { e setuju }\end{array}$ & $\begin{array}{c}\text { Persentase } \\
\text { tidak setuju }\end{array}$ & Total \\
\hline $\begin{array}{c}\text { Menjual } \\
\text { langsung }\end{array}$ & 19 & 40 & $32 \%$ & $68 \%$ & $100 \%$ \\
\hline $\begin{array}{c}\text { Potongan } \\
\text { kehidupan }\end{array}$ & 44 & 15 & $75 \%$ & $25 \%$ & $100 \%$ \\
\hline Gaya Hidup & 20 & 39 & $37 \%$ & $63 \%$ & $100 \%$ \\
\hline Fantasi & 13 & 36 & $22 \%$ & $78 \%$ & $100 \%$ \\
\hline $\begin{array}{c}\text { Suasana } \\
\text { atau citra }\end{array}$ & 24 & 35 & $41 \%$ & $59 \%$ & $100 \%$ \\
\hline Sumber: Data diolah, 2016 & & & & \\
\hline
\end{tabular}




\section{Hasil Uji Reliabilitas}

Uji Reliabilitas pada penelitian kali ini menggunakan rumus Ole $R$. Holsty, di mana peniti akan melakukan penetian dengan meng-coding data dan unit analisis yang telah ditetapkan bersama dengan dua pengcoding yang sebelumnya juga telah ditetapkan oleh penelitian

\section{Hasil Uji Reliabilitas Unit Analisis Formula Copywriting}

Uji Reliabilitas dalam unit analisis formula Copywriting terhitung CR (Coefisien Realibity) antara penguji 1 dan penguji 2 dan antara penguji 1 dan penguji 3 terdapat perbedaan hasil yaitu 0,94 dan 0,97 tapi kedua hasill tersebut menunjukan bahwa unit analisis formula copywriting adalah Reliabel.

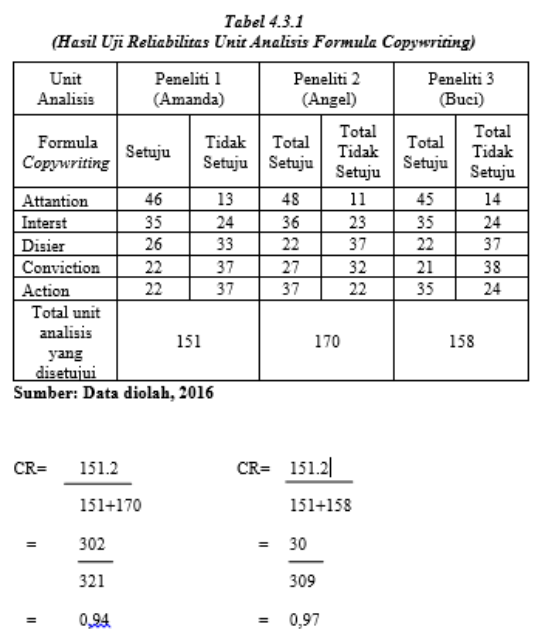

\section{Hasil Uji Reliabilitas Unit Analisis Isi Pesan}

Uji Reliabilitas dalam unit analisis isi pesan terhitung bahwa CR (Coefisien Realibity) antara penguji 1 dan penguji 2 dan antara penguji 1 dan penguji 3 terdapat kesamaan hasil yaitu 1 dan 1 tapi kedua hasil tersebut menunjukan bahwa unit analisis analisi isi pesan adalah Reliabel

\section{Hasil Uji Reliabilitas Unit Analisis Daya Tarik Pesan}

Uji Reliabilitas dalam unit analisis daya tarik terhitung bahwa CR (Coefisien Realibity) antara penguji 1 dan penguji 2 dan anatar penguji 1 dan penguji 3 terdapat perbedaan hasil yaitu 1,02 dan 1,01 tapi

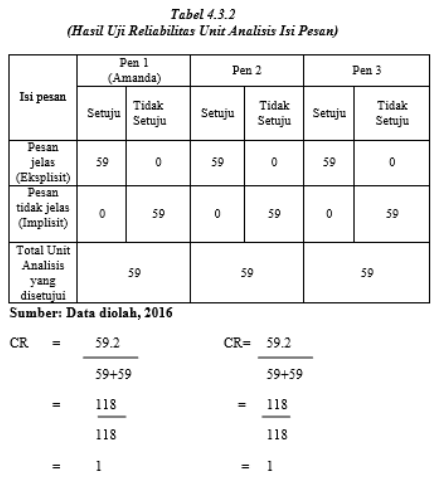

kedua hasill tersebut menunjukan bahwa unit analisis formula copywriting adalah Reliabel

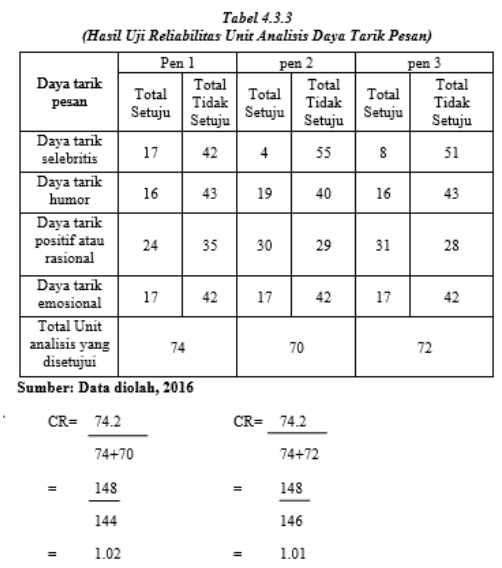

\section{Hasil Uji Reliabilitas Unit Analisis Gaya dalam Penyampaian Pesan}

Uji Reliabilitas dalam unit analisis formula Copywriting terhitung bahwa CR (Coefisien Realibity) antara penguji 1 dan penguji 2 dan anatar penguji 1 dan penguji 3 terdapat persamaan hasil yaitu 1 dan 1 tapi kedua hasill tersebut menunjukan bahwa unit analisis formula`copywriting adalah Reliabel.

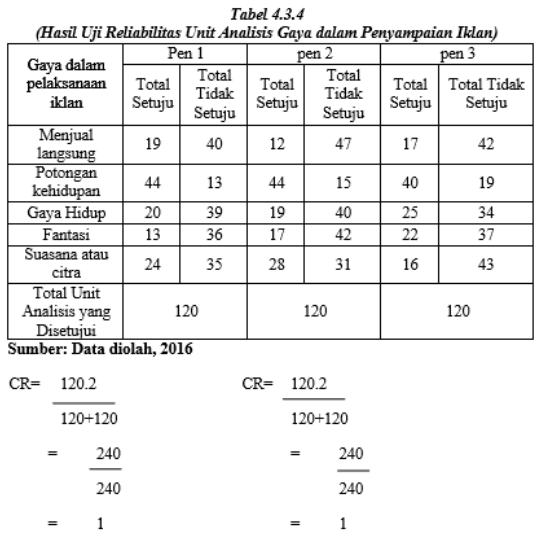




\section{KESIMPULAN DAN SARAN}

Kesimpulan bisa di dapat dari hasil penelitian ini ialah:

1. Sebanyak $78 \%$ atau sekitar 46 konten yang disetujui oleh peneliti karena menarik perhatian (Attention).

2. Seluruh isi konten yang telah diteliti tersampaikan secara jelas (esplisit)

3. Terdapat 24 konten yang menganung daya Tarik positif atau rasional.

4. Dalam analisis gaya dalam penyampaian pesan unsur potongan kehidupan adalah unsur terbanyak, yaitu 44 konten.

5. Seluruh unit analisis yang telah diteliti reliable.

\section{DAFTAR PUSTAKA}

Agustrijanto, "Seni Mengasah Kreativitas dan Memahami Bahasa Iklan”, Remaja Rosda Karya, 2001

Ashari, Zulfadhli, "The Secret of Copy Writing Revolution Strategis Konten Marketing Untuk Pebisnis Onlie”, EBOOK

Bungi, Burhan, 2006, “Teknik Praktis Riset Komunikasi, Disertau Contoh Paktis Riset Media, Public Relation, Advertising, Komunikasi Organisasi, Komunikasi Pemasaran”, Kencana, Jakarta

Darmadi Durianto, dkk. (2003). Invasi Pasar dengan Iklan yang Efektif. Jakarta: Gramedia Pustaka

Hakim, Budiman, 2006, "Lanturan Tapi Relevan”, Galang Press, Yogyakarta

Kasali, Rhenald, 1998, “ Membidik Pasar Indonesia, Segmentasi, Targeting, Positioning”, Gramedia Pustaka Utama, Jakarta

Kriyantono, Rachmat,2006, “ Teori Praktis Riset Komunikasi, Disertai Contoh Praktis Riset Media, Public Relations, Advertising, Komunikasi Organisasi, Komunikasi Pemasaran”, Kencana, Jakarta
Kurniawan, Rulianto, 2009, “Facebook untuk Orang Awam” Maxikom, Palembang

Marindo, Rex. 2013. Marketing Cappucino, Campur dan Racik Marketing Anda SesuaiSelera. Jakarta : PT. Elex Media Komputindo.

Morissan. 2010. "PERIKLANAN: Komunikasi Pemasaran Terpadu”. Jakarta: Kencana

Mulyana, Deddy, 2005, "Ilmu Komunikasi, Suatu Pengantar”, Remaja Rosdakarya, Bandung

Sandra Moriarty, dkk. 2011. "ADVERTISING". KENCANA, Jakarta

Santoso, Edi \& Setiansah, Mite.2010, “Teori Komunikasi”, Graha Ilmu, Yogyakarta

Shimp, Terence A. 2003. "Periklanan Promosi Aspek Tambahan Komunikasi Pemasaran Terpadu”. Erlangga, Jakarta

Suyanto, 2003, "Strategi Periklanan Pada E-Commerce Perusahaan Top Dunia”, Andi, Yogyakarta

Skripsi:

Tano Nazoeaggi, 2011, Analisis Isi Pesan Media Cetak Peraih Medali Emas Penghargaan Bulanan dalam Forum HTTP://www.adsoftheworld.com

Periode Oktober 2008 Hingga Maret 2011

Khairun Mutmainah, 2015, Pesan Dakwah pada Fan page Asma Nadia (ANALISIS ISI PESAN BULAN RAMADHAN 11436 H/ 2015

Ninda Puspita Sari, 2010, Efektifitas Iklan Social Media (Analisis EPIC Model Iklan "Maicih"

Jurnal:

Hariningsih Endang, 2013, Internet Advetising Sebagai Media Komunikasi Pemasaran Interaktif

Majalah:

Katalog Phinastika, 2011:16

Situs:

www.facebook.com/CadburyDairyMil 
Amanda A.F, Tuti Hartati dan Titik P. Analisis Konten Kreatif... 